\title{
Ocena ilości ciepła wprowadzonego do spoin i napoin metodą pomiaru ich pól poprzecznych w konwencjonalnych i hybrydowych procesach spawalniczych
}

\author{
Evaluation of the amount of heat introduced into the welds \\ and padding welds by means of their transverse fields \\ measurement in conventional and hybrid welding processes
}

\section{Streszczenie}

W pracy przedstawiono przyczyny niewystarczająco dokładnego opisu energii liniowej spawania i napawania zarówno w procesach konwencjonalnych, jak i hybrydowych. Wykonano badania spawania metodą MAG, laserem oraz hybrydowo (laser + MAG) wykazując niewłaściwość sumowania energii zużytej do spawania dla oceny ilości ciepła wprowadzonego. Przeprowadzono, na podstawie literatury, zestawienie energii liniowej dla złączy spawanych i napawanych oraz zaproponowano efektywny sposób obliczania i uporządkowania energii liniowej spawania lub napawania.

Słowa kluczowe: ciepło wprowadzone; procesy hybrydowe; energia liniowa spawania

\begin{abstract}
The paper presents the causes of insufficiently detailed description of the heat input of welding and hardfacing in both conventional and hybrid processes. MAG, laser and hybrid (laser + MAG) welding experiments were performed, showing the incomplete aggregation of the consumed energy for welding to assess the amount of heat introduced. Based on the literature, heat input for welded joints and padding welds was calculated, and an effective way of calculating and arranging the heat input of welding or hardfacing was proposed.
\end{abstract}

Keywords: heat input; hybrid processes; linear energy of weld

\section{Wstęp}

Ciepło wprowadzone (ang. heat input) do materiałów spajanych odniesione do długości wykonanych spoin lub napoin jest jednym z podstawowych technologicznych parametrów procesów spawania lub napawania. Definiowane jest jako energia liniowa i opisywane prostą zależnością (1):

$$
E_{1}=\frac{E}{l}=\frac{q}{v}=\frac{\eta U I}{v}, \frac{\mathrm{J}}{\mathrm{mm}}
$$

gdzie:

$\mathrm{E}_{\mathrm{I}}$ - energia liniowa, $\mathrm{J} / \mathrm{mm}$;

E - energia wprowodzana, J;

I - długość spoiny/napoiny, mm;

q - moc skuteczna źródła ciepła, W;

v - prędkość liniowa spawania/napawania dla spawania łukowego, $\mathrm{mm} / \mathrm{s}$;

$\eta$ - współczynnik sprawności procesu;

U - napięcie łuku, V;

I - natężenie prądu spawania/napawania, $A$.
Podawana jest w instrukcjach technologicznych spawania (WPS), wytycznych i normatywach spawania stali oraz metali nieżelaznych i ich stopów. Przez wiele lat wzór wystarczał do definiowania poprawności i kontroli stabilności elektrycznych procesów spawalniczych.

Wszechstronny rozwój spawalnictwa doprowadził jednak do objęcia procesami łączenia termicznego nowych materiałów, których wrażliwość na miejscowe oddziaływanie ciepła jest znacząco większa niż niskowęglowych stali konstrukcyjnych. Są to m.in. stale energetyczne nowej generacji, stopy niklu, dyspersyjnie utwardzone stopy aluminium, stale obrobione termomechanicznie oraz wiele innych materiałów konstrukcyjnych $[1 \div 3]$.

Postępy inżynierii materiałowej wymusiły jednocześnie wynalezienie i dopracowanie nowych, precyzyjnych i wyspecjalizowanych metod spajania, których oddziaływanie cieplne na zespalane elementy powoduje niewielkie zmiany

Dr inż. Kwiryn Wojsyk, mgr inż. Michał Macherzyński - Politechnika Częstochowska, mgr inż. Rafał Lis - Wielton S.A.

Autor korespondencyjny/Corresponding author: kwiryn@gmail.com 
metalograficzne i naprężeniowo-odkształceniowe w obrębie złączy. Brak jakichkolwiek odchyleń właściwości łączonych materiałów od pożądanych w miejscach łączenia jest docelowym zadaniem spawalnictwa.

Dlatego też nowo powstające materiały konstrukcyjne są spajane technologiami gwarantującymi minimalną, konieczną ingerencję cieplną, wytyczoną bardzo wąsko dobieranymi parametrami [1]. Okazało się jednak, że jeżeli stosowane są impulsowe bądź hybrydowe metody spawania, szacowanie ilości ciepła wprowadzonego do materiałów spawanych staje się zawodne [4,5], a opieranie się w tym celu na zależności (1) jest bezużyteczne.

Sprawę komplikuje dodatkowo szereg innych czynników, mających niewątpliwy wpływ na sprawność procesów spawania lub napawania, a zatem na ilość ciepła wprowadzonego w ich trakcie. Niektóre z nich pokazano na rysunku 1.

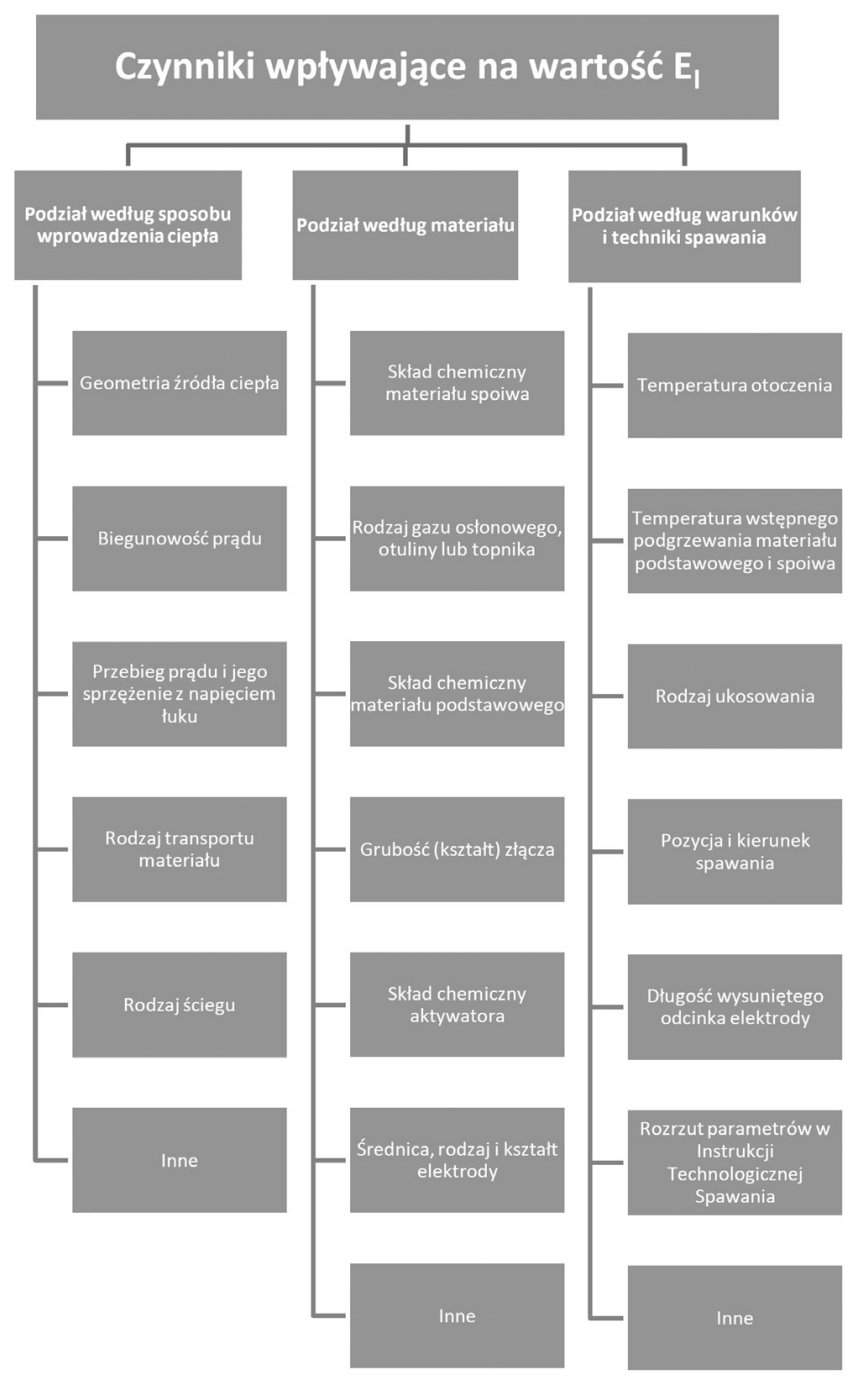

Rys. 1. Czynniki wpływające na wartość energii liniowej spawania $E_{\mid}$ Fig. 1. Factors which affect the heat input of $E_{\text {l welding }}$

Uwzględnienie pokazanych na rysunku 1 czynników zakłócających szacowanie ciepła wprowadzonego do elementów spajanych praktycznie uniemożliwia korzystanie z zależności (1) w celu uzyskania w miarę dokładnego obliczenia E. Każdy z nich bowiem może być wyznaczony z kilkunasto-kilkudziesięciu procentową dokładnością, a kolejne ich wymnażanie prowadzi do znacznych rozbieżności rezultatu końcowego $[6,7]$.

Nie wydaje się zatem możliwe szacowanie energii liniowej spawania przez opieranie się na tzw. zewnętrznych technologicznych parametrach procesów spawania lub napawania.
Perspektywicznym podejściem może być natomiast ocena efektów spawalniczego oddziaływania cieplnego na podstawie śladu cieplnego.

Prowadzone są w tym kierunku prace teoretyczne oparte o symulacje zachowań termomechanicznych materiałów w warunkach oddziaływania różnorodnych cykli cieplnych

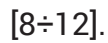

Ostatecznymi miernikami działania źródeł cieplnych mogą być bowiem materiałowe parametry wynikowe procesu termomechanicznego takie jak:

- objętość przetopienia;

- objętość lub szerokość zmian strukturalnych w strefach wpływu ciepła spoin lub napoin;

- wielkość maksymalna i rozkład pola naprężeń w złączu;

- wielkość odkształceń ostatecznych - wzdłużnych lub poprzecznych;

- maksymalna lub minimalna twardość w strefach wpływu ciepła;

- minimalny poziom udarności złącza.

Jak pokazano $\mathrm{w}$ pracy [11] stosunkowo prostym i wygodnym sposobem oceny wprowadzonego przez źródło ciepła jest pomiar jednego z efektów jego działania - pola poprzecznego spoiny lub napoiny, będącego reprezentacją objętości przetopienia.

W celu wyznaczenia energii liniowej procesu należy wyznaczyć na zgładzie metalograficznym pola przetopienia zgodnie np. z procedurą pokazaną na rysunku 2.

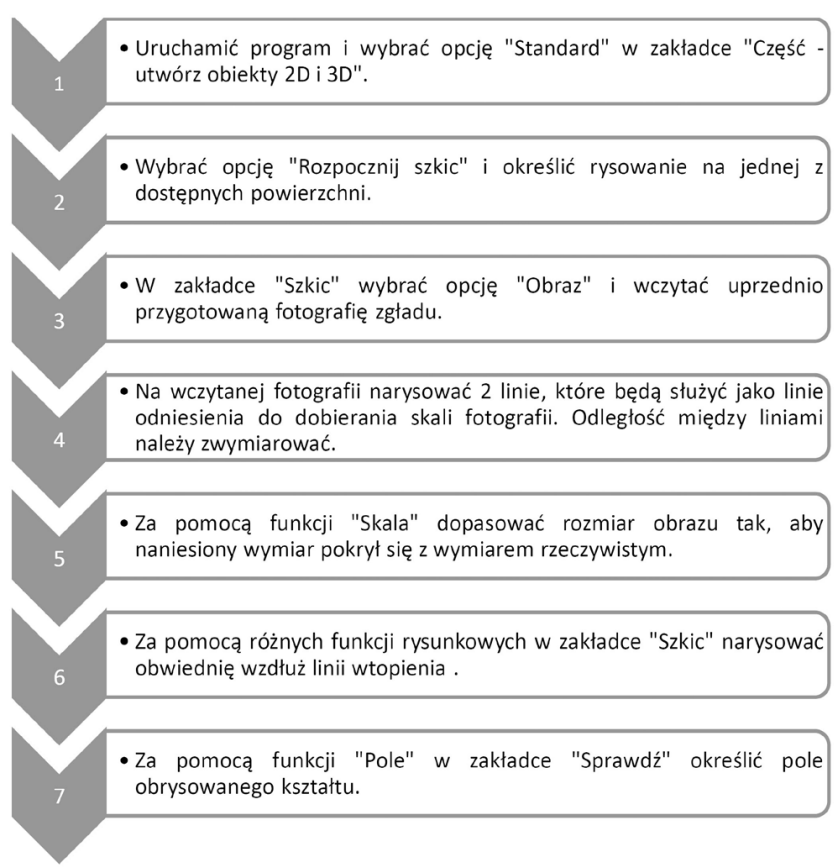

Rys. 2. Procedura wyznaczania pola poprzecznego przekroju spoiny (napoiny) przy użyciu np. programu Autodesk Inventor Professional - wersja studencka

Fig. 2. Procedure for determining the cross-sectional area of a weld (padding weld) using, for example, Autodesk Inventor Professional - student version

Dla rozważań dokonywanych w niniejszej pracy istotne jest to, że niezależnie od metody spawania lub ich kombinacji wyznaczyć można wielkość pola poprzecznego otrzymanej spoiny (napoiny). Zatem metoda ta jest przydatna do oceny efektywności spawania łukowego - konwencjonalnego lub jego odmian pulsacyjnych, spawania laserem, wiązką elektronów, napawania, przetapiania powierzchniowego, a także różnorodnych metod hybrydowych. 
W tablicy I przedstawiono wyniki badań uzyskanych przez różnych autorów, które zostały opublikowane w ostatnich latach na łamach Przeglądu Spawalnictwa, Biuletynu Instytutu
Spawalnictwa, a także w materiałach Sympozjum Katedr i Zakładów Spawalnictwa [12 $\div 24]$, a na rysunku 3 ich zestawienie $w$ formie wykresu.

Tablica I. Określenie pól poprzecznych spoin i napoin

Table I. Determination of the transverse field of welds and padding welds

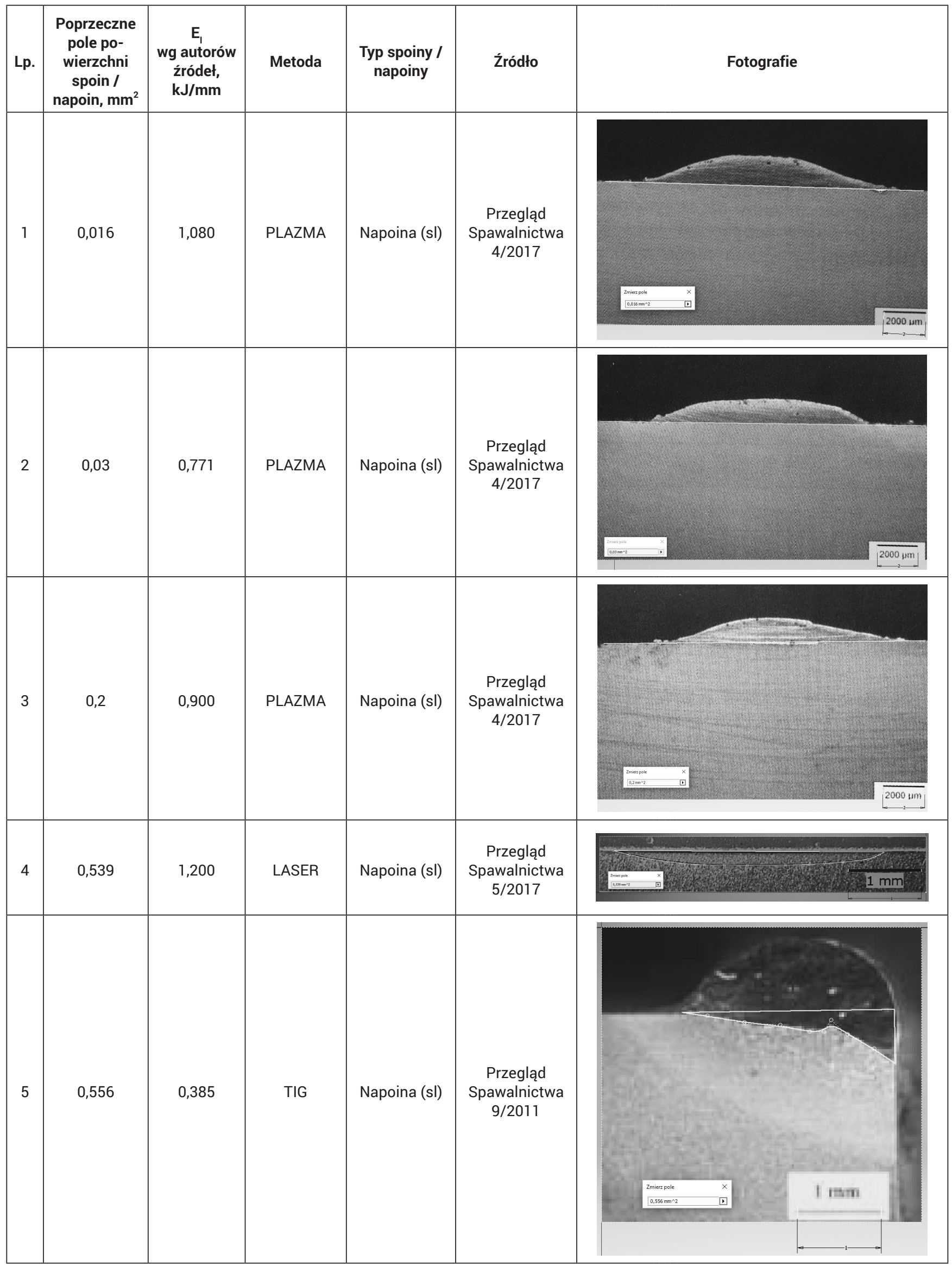


CD. Tablica I. Określenie pól poprzecznych spoin i napoin

Cont. Table I. Determination of the transverse field of welds and padding welds

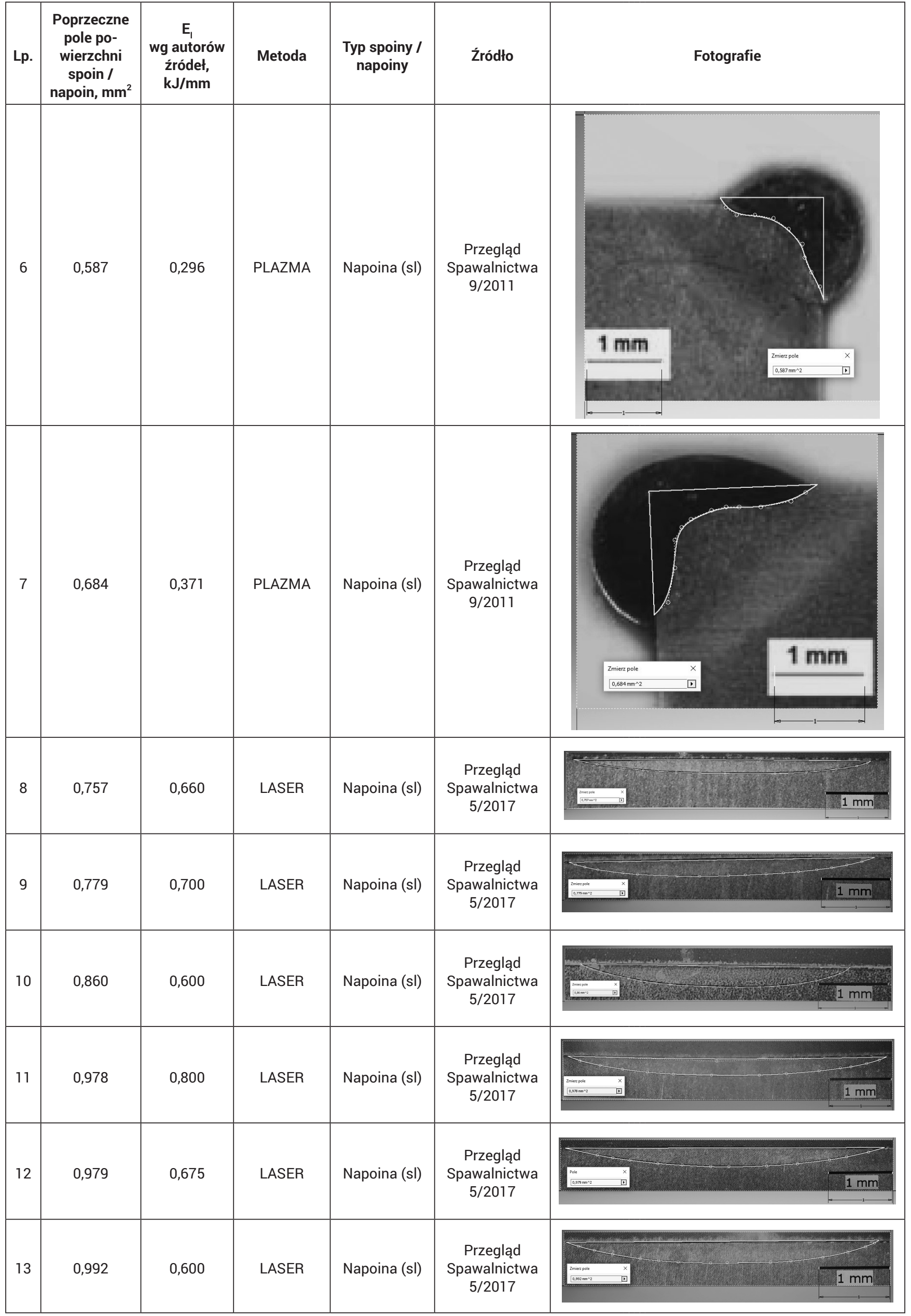


CD. Tablica I. Określenie pól poprzecznych spoin i napoin

Cont. Table I. Determination of the transverse field of welds and padding welds

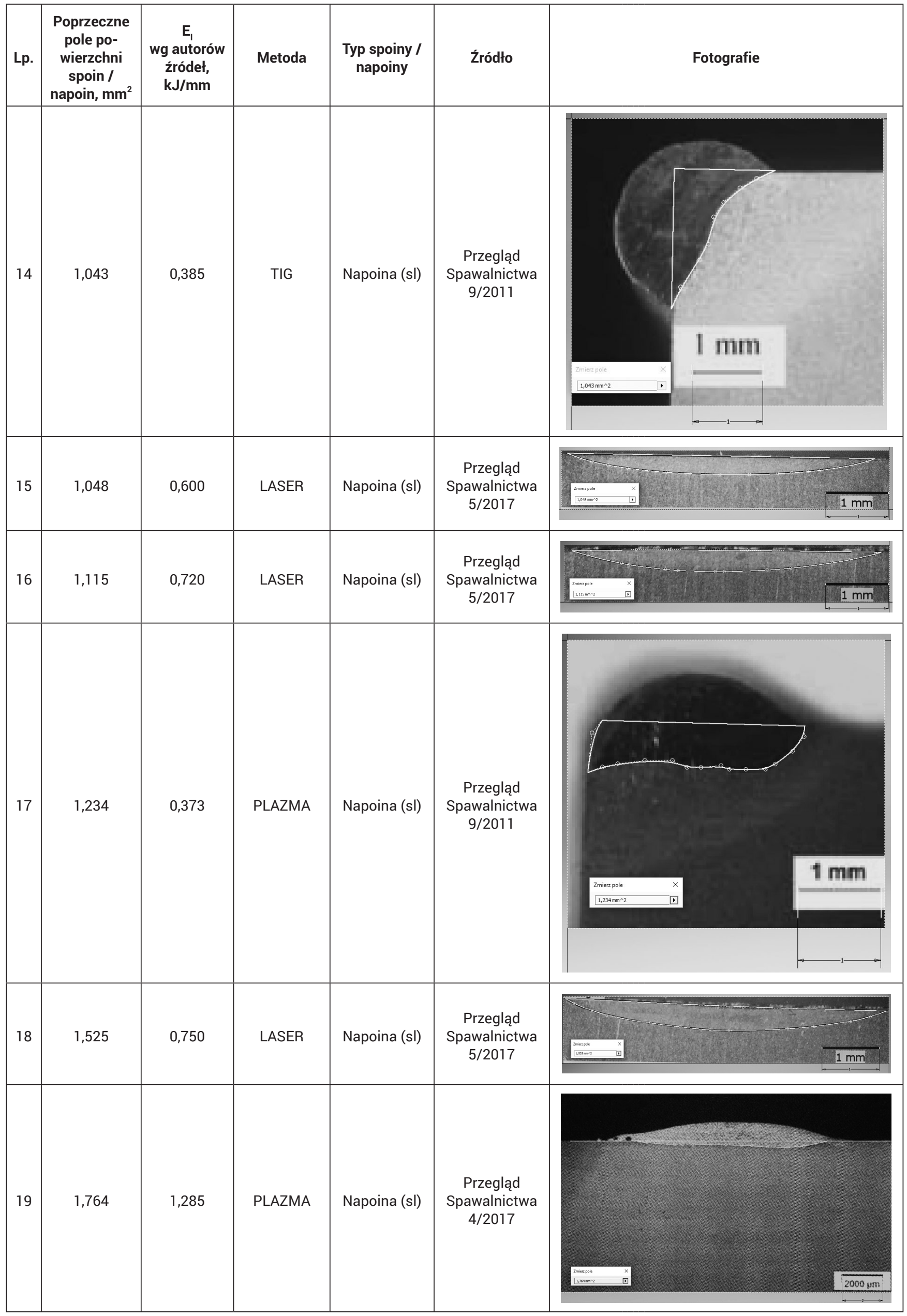


CD. Tablica I. Określenie pól poprzecznych spoin i napoin

Cont. Table I. Determination of the transverse field of welds and padding welds

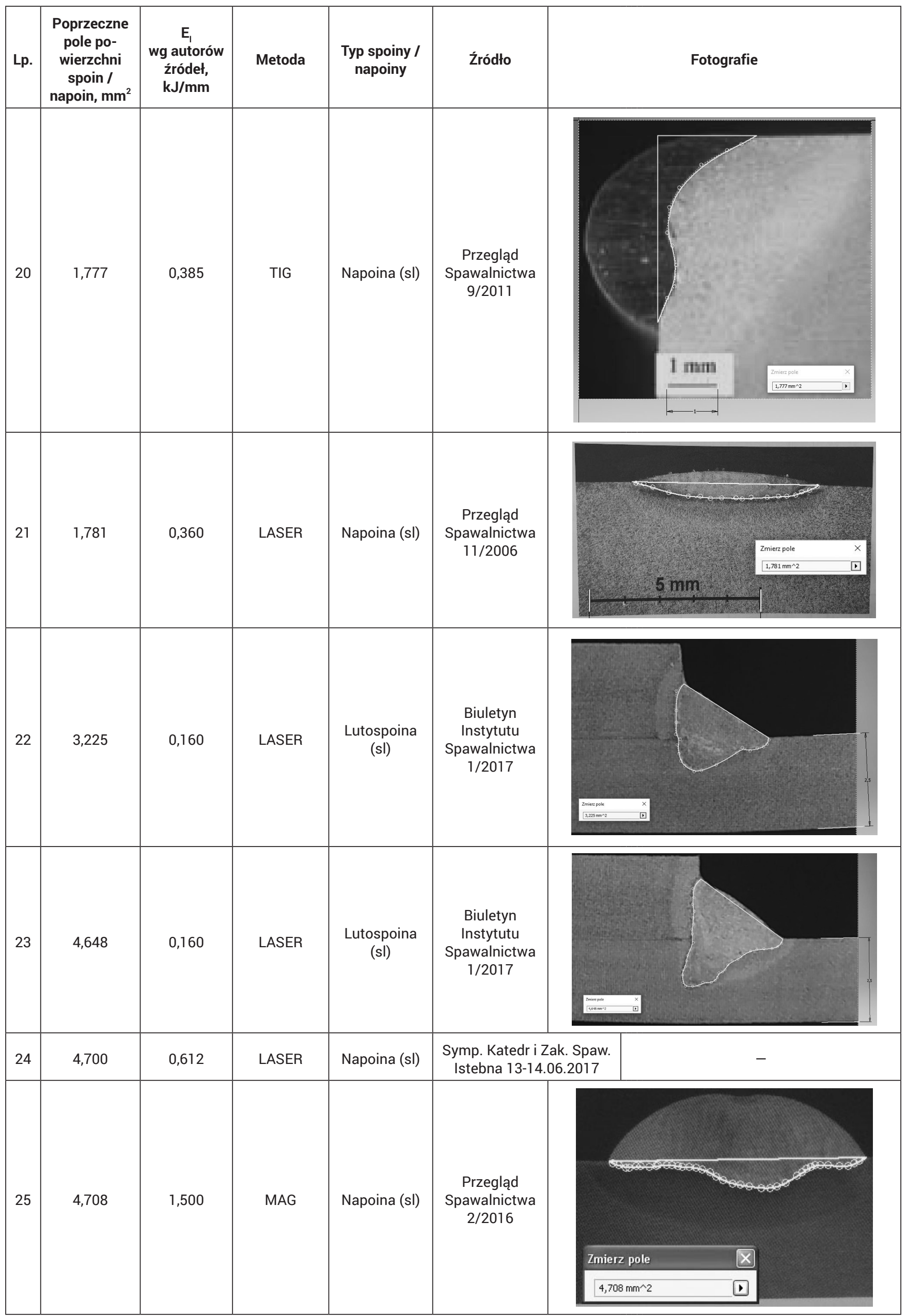


CD. Tablica I. Określenie pól poprzecznych spoin i napoin

Cont. Table I. Determination of the transverse field of welds and padding welds

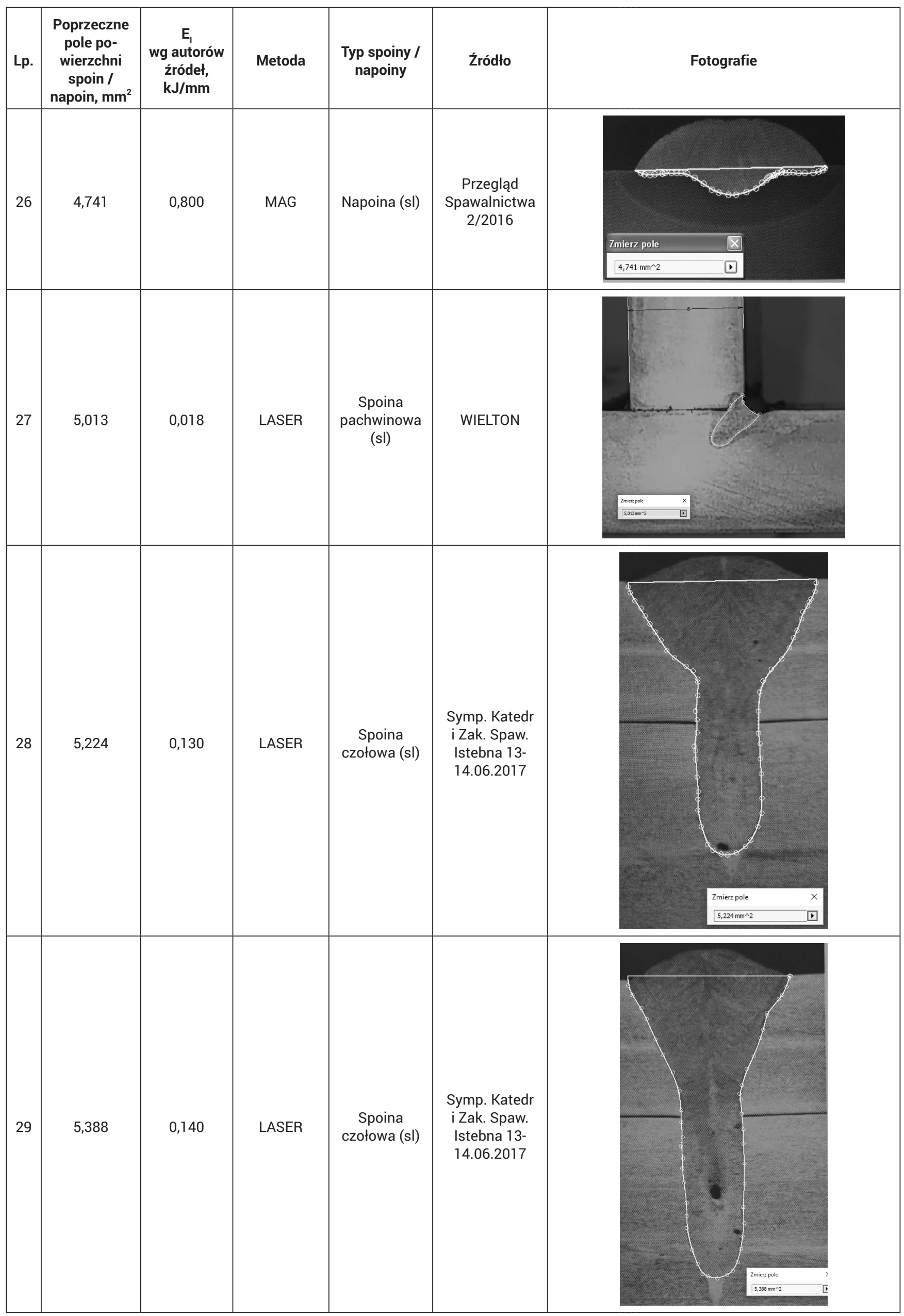


CD. Tablica I. Określenie pól poprzecznych spoin i napoin

Cont. Table I. Determination of the transverse field of welds and padding welds

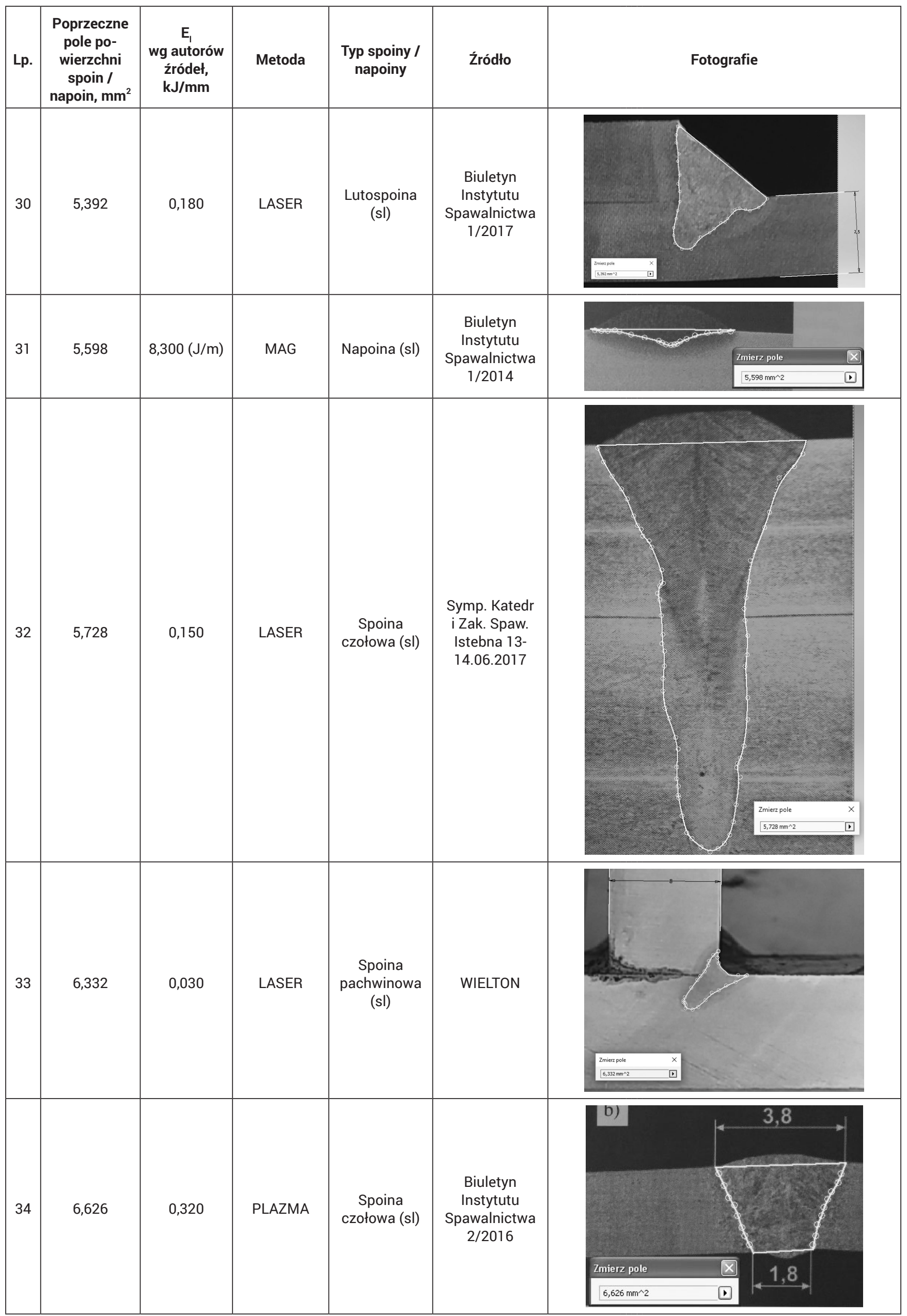


CD. Tablica I. Określenie pól poprzecznych spoin i napoin

Cont. Table I. Determination of the transverse field of welds and padding welds

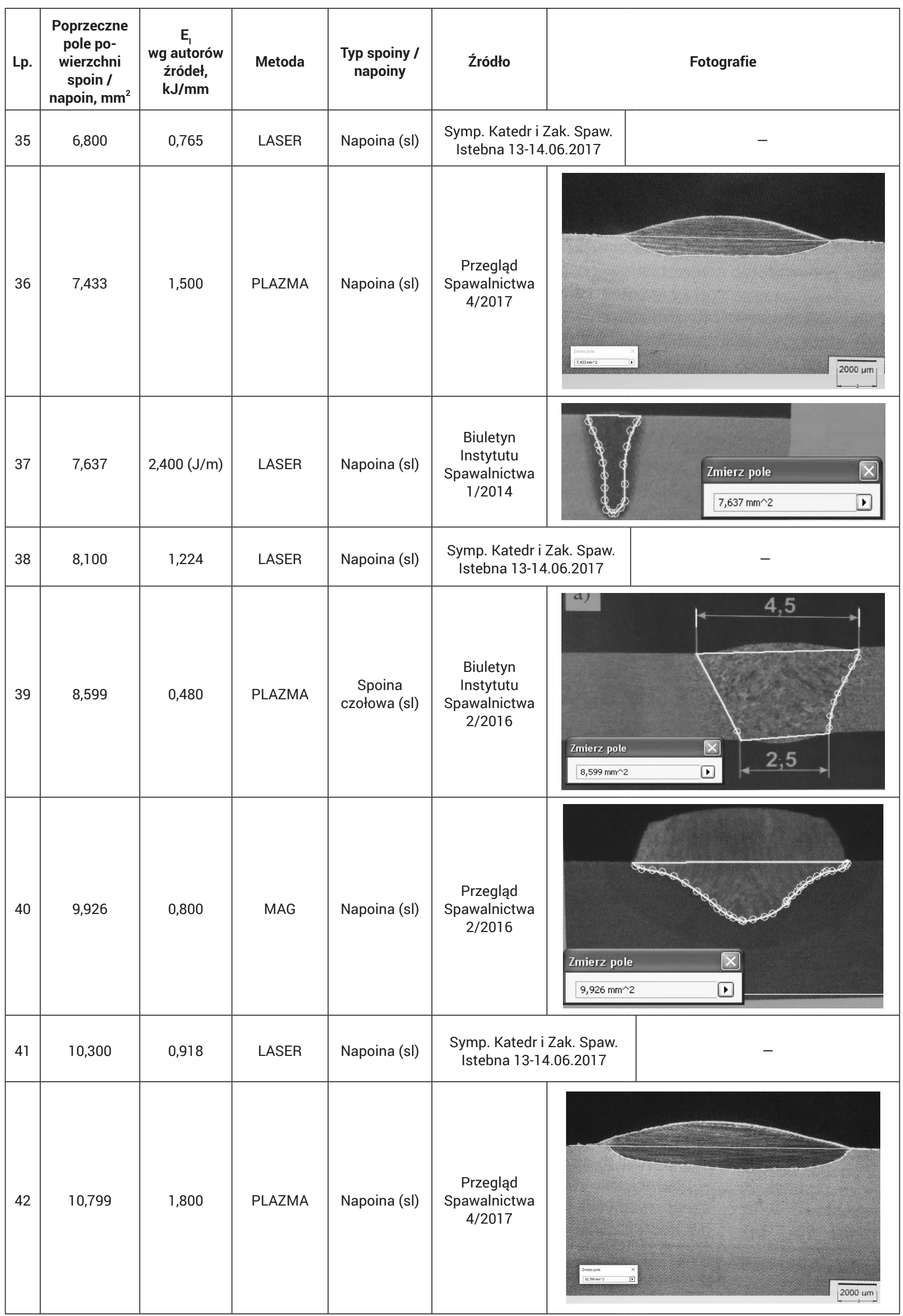


CD. Tablica I. Określenie pól poprzecznych spoin i napoin

Cont. Table I. Determination of the transverse field of welds and padding welds

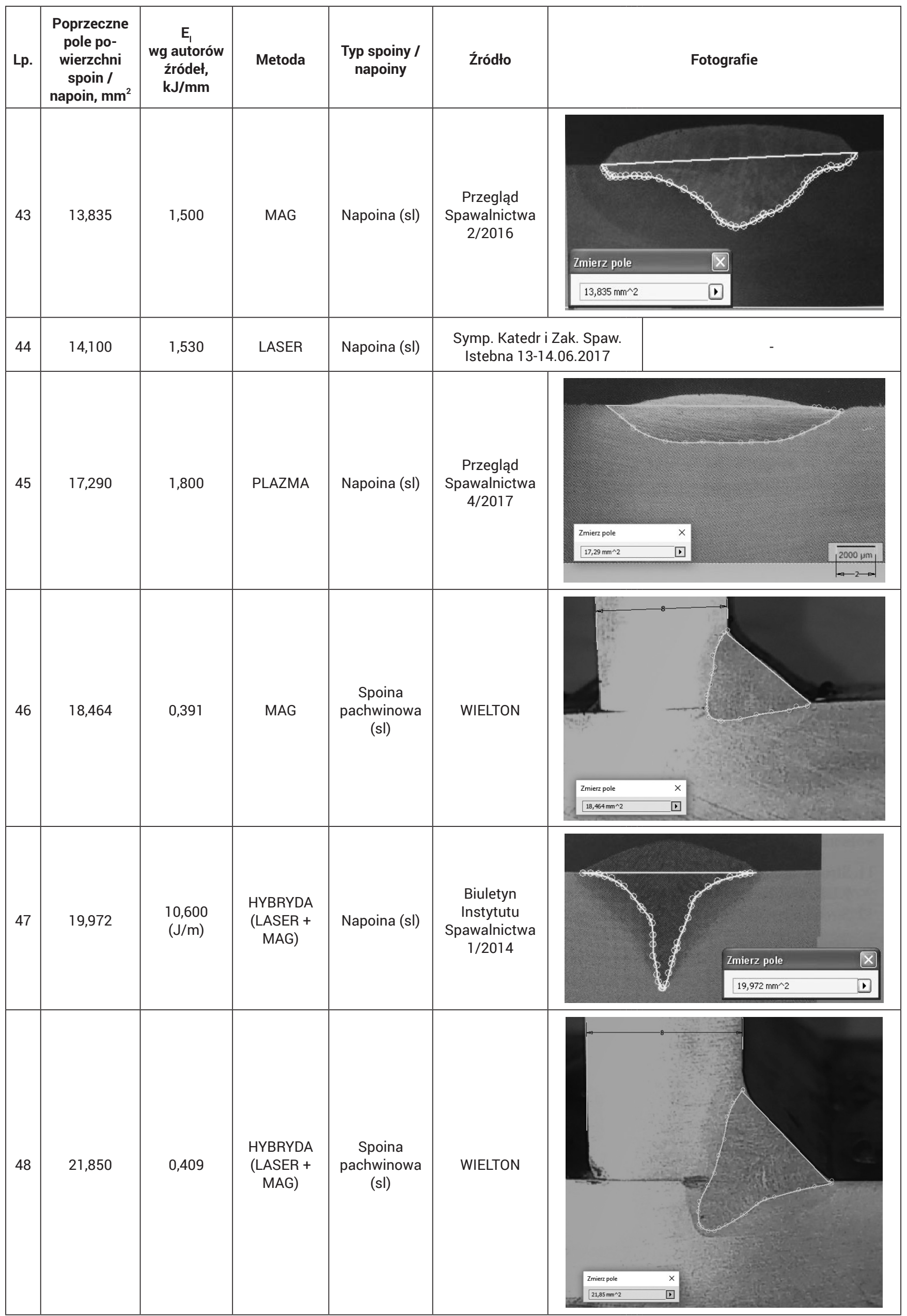


CD. Tablica I. Określenie pól poprzecznych spoin i napoin

Cont. Table I. Determination of the transverse field of welds and padding welds

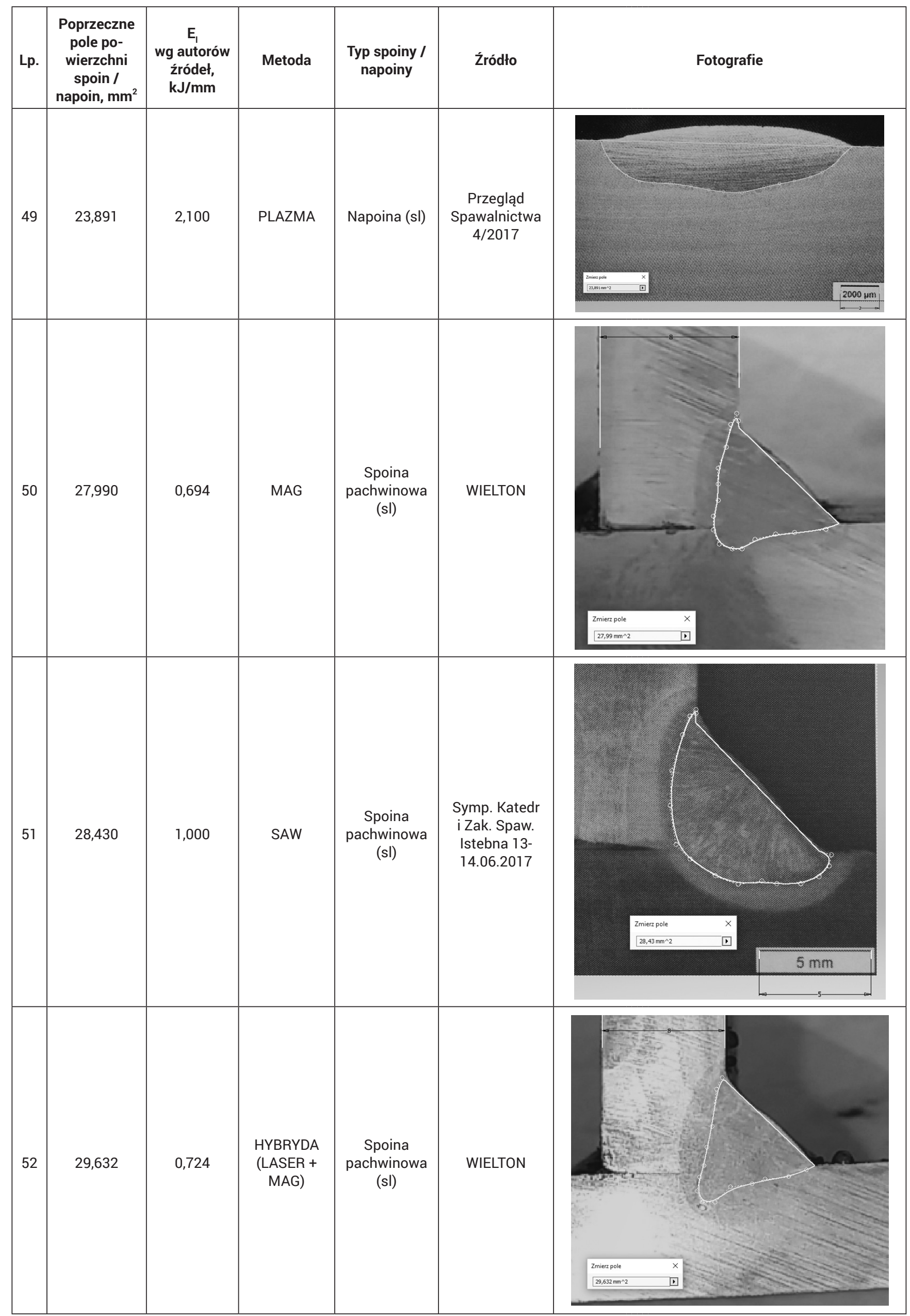


CD. Tablica I. Określenie pól poprzecznych spoin i napoin

Cont. Table I. Determination of the transverse field of welds and padding welds

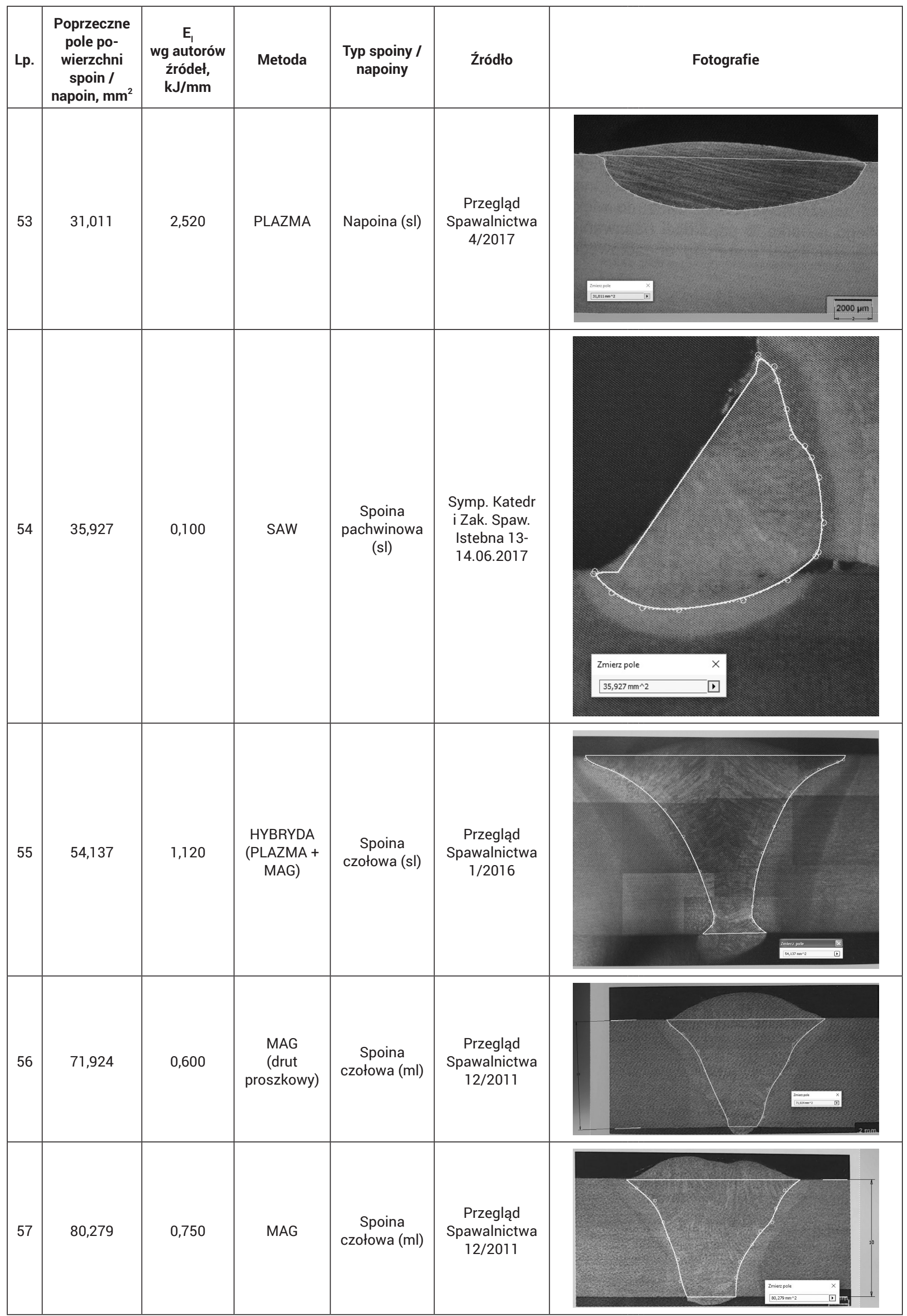


CD. Tablica I. Określenie pól poprzecznych spoin i napoin

Cont. Table I. Determination of the transverse field of welds and padding welds

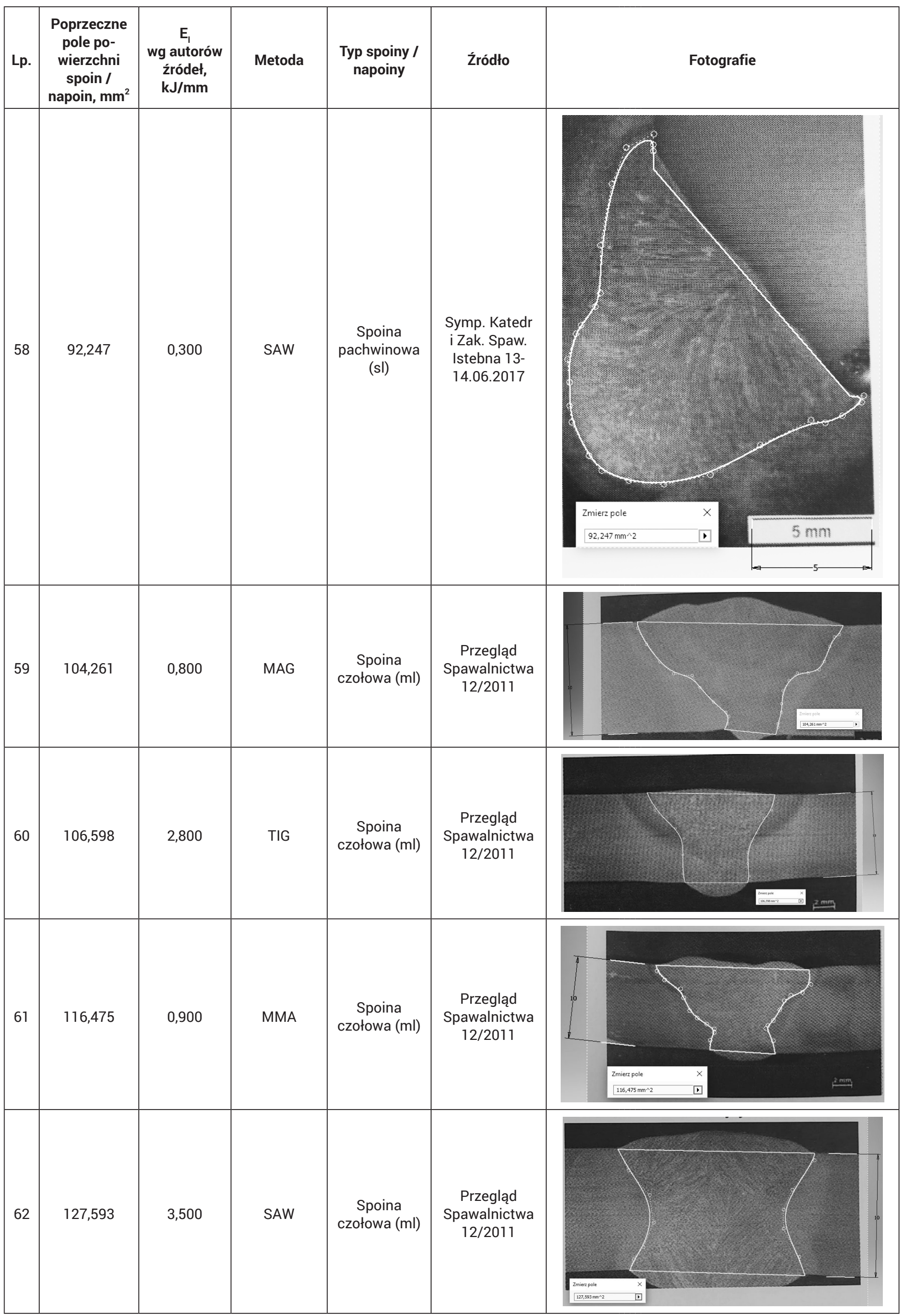


Tablica II. Skład chemiczny i własności mechaniczne stali martenzytycznej DOCOL 1200M

Table II. Chemical composition and mechanical properties of martensitic steel DOCOL 1200M

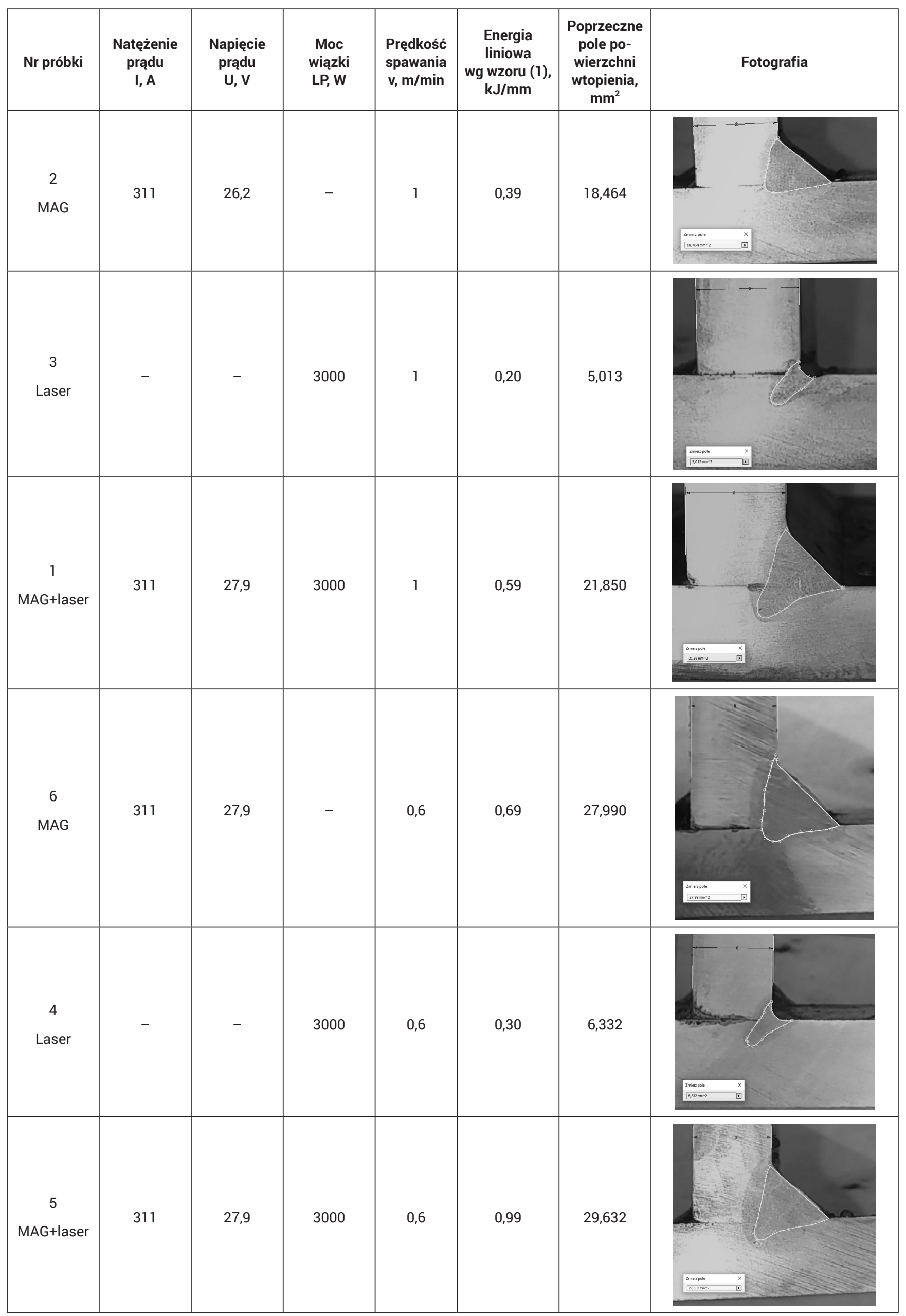




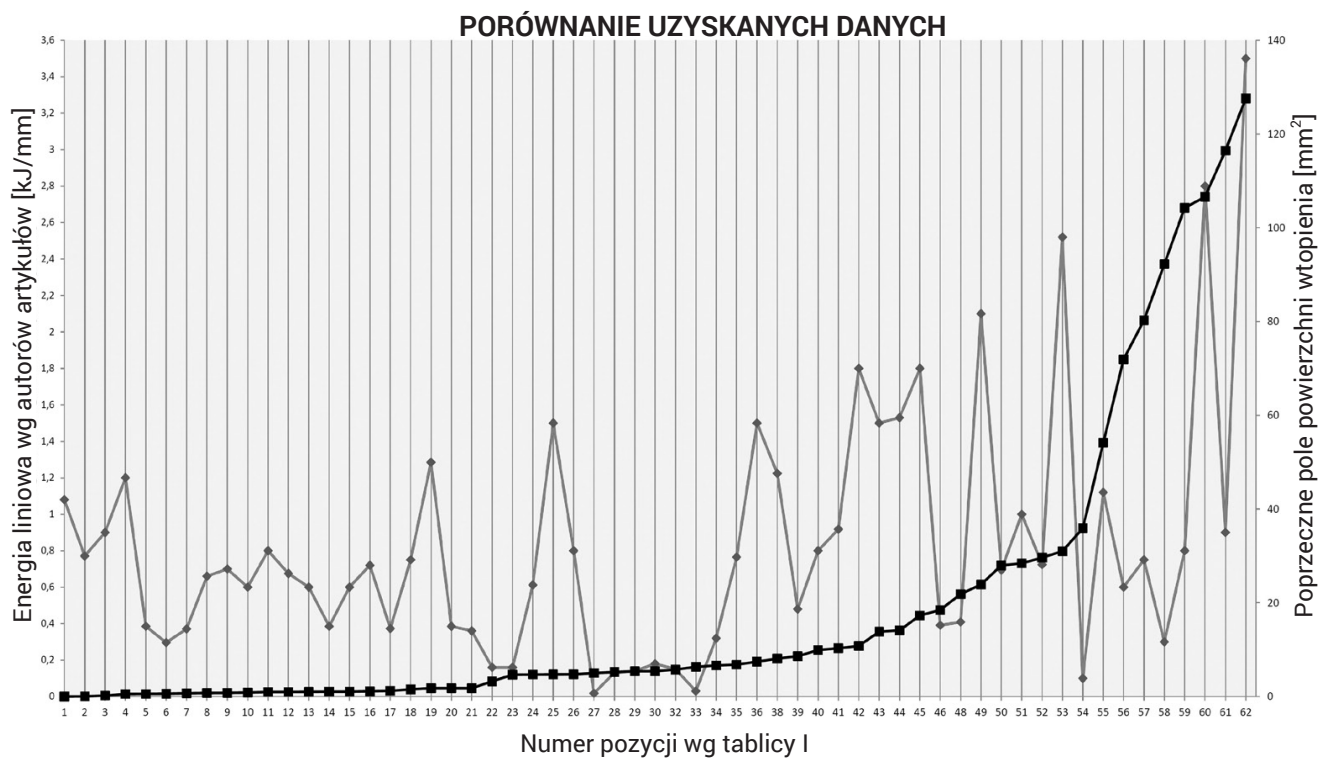

Rys. 3. Uporządkowanie energii liniowej spawania i napawania metodą pomiaru ich pól poprzecznych

Fig. 3. Order of the heat input of welding and hardfacing by measuring their transverse fields
Wykres wykonano zakładając, że większa objętość przetopienia odpowiada większej rzeczywistej energii liniowej spawania (napawania). Do badań porównawczych włączono rezultaty autorskich eksperymentów przeprowadzonych w warunkach przemysłowych na identycznych złączach teowych spawanych odpowiednio: metodą MAG, laserem i hybrydowo (MAG + laser) - tablica II.

Zsumowano obliczone energie liniowe spawania metodą MAG i laserem oraz pola przetopienia powstające w wyniku zastosowania tych metod.

Okazało się, że pole przetopienia wynikające z zastosowania spawania hybrydowego jest mniejsze o 6,9\% dla niższych parametrów spawania i o 13,7\% dla wyższych parametrów od sumy pól przetopień w przypadku niezależnego spawania metodą MAG i laserem. Do tablicy I włączono te dane.

$\mathrm{Na}$ osi poziomej rysunku 3 uszeregowano efekty ingerencji cieplnej w procesach spawania lub napawania od małych do dużych pól przetopienia.

$\mathrm{Na}$ osi pionowej przedstawiono wielkości energii liniowej spawania proporcjonalnie do pola (objętości) przetopienia.

Linia czerwona przedstawia podane przez autorów prac $[12 \div 24]$ wartości energii liniowej spawania lub napawania obliczane wg dotychczasowej metodyki.

Można zaobserwować brak korelacji między zużytą na przetopienie energią liniową a objętością przetopienia.

\section{Wnioski}

1. Opracowanie skutecznej metody szacowania energii liniowej spawania lub napawania jest niezbędne.

2. Konieczne jest powiązanie energii liniowej ze śladem cieplnym pozostawionym w materiałach nagrzewanych.

3. Perspektywiczne wydaje się oparcie szacowania ciepła wprowadzonego (heat input) na poprzecznych polach przetopienia spoin lub napoin.

\section{Literatura}

[1] Brózda J.: Seminarium dotyczące stali dla nowoczesnych wysokowydajnych elektrowni i materiałów dodatkowych do ich spawania, Rudy Raciborskie 15.02.2019, Biuletyn Instytutu Spawalnictwa 2/2009, s. 12-15.

[2] Nowacki J.: Stal dupleks i jej własności, WNT, Warszawa 2009.

[3] Górka J.: Własności i struktura złączy spawanych stali obrabianej termomechanicznie o wysokiej granicy plastyczności, Gliwice, Wyd. Pol. Śląskiej 2013, s. 129-142.

[4] Kudła K., Wojsyk K.: Czy sposób doprowadzania ciepła ma istotny wpływ na geometrię spoin? Biuletyn Instytutu Spawalnictwa w Gliwicach 5/2012, s. 140-144

[5] Wojsyk K., Macherzyński M.: Określanie energii liniowej spawania metodą pomiaru pól poprzecznych spoin, Biuletyn Instytutu spawalnictwa 5/2016, Gliwice 2016, s. 75-79.

[6] Słania J., Ptaszek D.: Analiza rozrzutu parametrów w Instrukcji Technologicznej Spawania na przykładzie wybranych metod spawania, Przegląd Spawalnictwa, vol. 89, nr 2/2017, s. 14-31.

[7] Kensik R.: Ocena energii liniowej w procesach MIG/MAG, Przegląd Spawalnictwa 9-10/2006, s. 5-8.

[8] Rochalski D., Golański D., Chmielewski T.: Modele spawalniczych źródeł ciepła w analizie pola temperatury. Przegląd Spawalnictwa 5/2017, s. 109-112.
[9] Grolik L.: Zmiany kształtu geometrycznego jeziorka ciekłego metalu w zależności od ilości ciepła wprowadzonego w procesie spawalniczym, Biuletyn Instytutu Spawalnictwa 3/2017, s. 60-64.

[10] Wojsyk K.: Badanie metodą termograficzną energii liniowej spawania i napawania, Przegląd Spawalnictwa 8/2007, s. 34-38.

[11] Kudła K., Wojsyk K.: Normowa energia liniowa a ilość ciepła wprowadzanego podczas spawania, Przegląd Spawalnictwa nr 12/2010, s. 21-25.

[12] Górka J.: Właściwości spoin stali obrabianych termomechanicznie o wysokiej granicy plastyczności, Przegląd Spawalnictwa 12/2011, s. 31-35.

[13] Szulc J., Chmielewski T., Pilat Z.: Zrobotyzowane spawanie hybrydowe Plazma+MAG stali S700MC, Przegląd Spawalnictwa 1/2016, s. 43.

[14] Górka J., Opiela M.: Przetapianie plazmowe stali mikroskopowej typu HSLA, Sympozjum Katedr i Zakładów Spawalnictwa, Istebna 14.06.2017, s. 81-89.

[15] Bober M.: Badania wpływu głównych parametrów napawania plazmowego na geometrię napoin w oparciu o metody planowania eksperymentu, Przegląd Spawalnictwa, Vol. 89, Nr 4/2017, str. 5-9.

[16] Banasik M., Stano S., Urbańczyk M.: Spawanie hybrydowe laser + łuk elektryczny. Rozwój i możliwości metody (Część I), Biuletyn Instytutu Spawalnictwa 1/2014, str. 34-40. 
[17] Luksa K., Olbrich R., Bednarek M.: Wpływ warunków wykonania napoin na własności stali ARMOX370T w obszarze wokół napoiny, Przegląd Spawalnictwa 2-2016, s. 28-30.

[18] Różański M., Topolski M.: Spawanie plazmowe stali CPW800, Biuletyn Instytutu Spawalnictwa 2/2016, s. 28-30.

[19] Stano S., Różański M., Grajcar A.: Wpływ parametrów procesu lutospawania na strukturę i własności mechaniczne połączeń ze stali CPW800. Cz. Il: Lutospawanie laserowe, Biuletyn Instytutu Spawalnictwa 1/2017, s. 31-35.

[20] Klimpel A., Dobrzański L., Nowacki J.: Napawanie laserowe proszkiem niklowym żeliwa sferoidalnego stopowego Si-Mo, Przegląd Spawalnictwa $11 / 2006$, s. 32-35
[21] Wyględacz B., Kik T., Janicki D.: Symulacja numeryczna i badania cykli cieplnych hartowania laserowego stali narzędziowej WCL, Przegląd Spawalnictwa 5/2017, s. 91-95.

[22] Kik T., Górka J., Czupryński A., Martyniszyn A.: Napawanie krawędzi przedmiotów metodami TIG i PTA, Przegląd Spawalnictwa 9/2011, s. 79-86.

[23] Lisiecki A., Wójciga P., Kurc-Lisiecka A., Barczyk M., Krawczyk S.: Spawanie laserem złączy zakładkowych ze stali AISI30A, Sympozjum Katedr i Zakładów Spawalnictwa, Istebna 13-14.06.2017, str. 37-46.

[24] Górka J.: Struktura i własności złączy teowych ze stali TMCP wykonanych łukiem krytym, Sympozjum Katedr i Zakładów Spawalnictwa, Istebna 13-14.06.2017, s. 47-58. 